\title{
WEED INFESTATION OF A CEREAL-LEGUME MIXTURE DEPENDING ON ITS CONCENTRATION AND POSITION IN A CROP ROTATION
}

\author{
Marta K. Kostrzewska, Maria Wanic, Magdalena Jastrzębska \\ Department of Agricultural Systems, University of Warmia and Mazury in Olsztyn, Plac Łódzki 3, 10-718 Olsztyn, Poland \\ e-mail: marta.kostrzewska@uwm.edu.pl
}

Received: $10.03 . .2012$

\begin{abstract}
A field study was carried out in the period 2000-2006 at the Experimental Station in Tomaszkowo belonging to the University of Warmia and Mazury in Olsztyn. Its aim was to compare weed infestation of a mixture of spring barley and field pea grown in a four crop rotation with different crop selection and sequence. Each year during tillering of spring barley and before the harvest of the mixture, weed species composition and density were evaluated, while additionally weed biomass was also estimated before the harvest. These results were used to determine species constancy, Simpson's dominance index, the Shannon-Wiener diversity and evenness indices as well as the community similarity index based on floristic richness, numbers and biomass of particular weed species. The cropping frequency and the position of the mixture in the crop rotation did not differentiate the species composition and total biomass of weed communities in the cereal-legume mixture crops. The crop rotation in which the mixture constituted 50\% and was grown after itself had a reducing effect on weed numbers. Growing field pea in the 4-year crop rotation promoted weed infestation of the mixture and the dominance of weed communities. Capsella bursa-pastoris, Chenopodium album, Echinochloa crus-galli, Elymus repens, Polygonum convolvulus, and Sonchus arvensis were constant components of the agrophytocenoses. The weed communities were more similar in terms of their floristic composition than in terms of weed density and air-dry weight of weeds.
\end{abstract}

Key words: mixture of spring barley and field pea, crop rotation, weeds, constancy, species diversity, community similarity

\section{INTRODUCTION}

Crop rotation is a controlled crop succession system in agroecosystems. Crop selection and sequence affect the formation of new phytocenoses. The crop plant (as the dominant component) and weeds are constant components of the community being formed.
Changes in the floristic composition of unwanted vegetation and their quantitative relationships relative to the crop rotation, also taking into account other elements of agricultural practice, are a theme that is often found in scientific literature. Scientific research is usually focused on weed infestation of crops in pure stand, less frequently of interspecific mixtures.

Cereal mixtures are more popular in cultivation than cereal-legume mixtures, though the latter ones are characterized by a higher value as a previous crop and a higher commercial value of yield, but at the same time agricultural practice used to grow these mixtures is more difficult ( $\mathrm{R} \mathrm{u} \mathrm{d} \mathrm{n} \mathrm{i} \mathrm{c} \mathrm{k} \mathrm{i,} \mathrm{1999).} \mathrm{Weeds} \mathrm{can} \mathrm{pose}$ a problem, but weed infestation and its changes in mixed cereal-legume crops are poorly known. In recent years, some papers have been published which inform about the influence of the proportion of mixture components, herbicides, and nitrogen rates on weed density and biomass (Rudnicki and Wenda-Piesik, 2002; Poggio, 2005; B u raczyńska， 2009; $\mathrm{Hauggaard-Nielsen} \mathrm{et} \mathrm{al.} \mathrm{2006;} \mathrm{Jędrusz-}$ czak et al. 2006; Sobkowicz and Podgórska-Lesiak, 2007; Staniak and Księżak, 2010). The effect of previous crops and cropping frequency in a crop rotation system is also an important problem and this paper is devoted to this issue.

The aim of the present study was to compare weed communities in spring barley and field pea mixture crops grown in four crop rotations (with its proportion of 25 and 50 percent) with different crop selection and sequence.

\section{MATERIALS AND METHODS}

The study results come from a static field experiment carried out in the period 2000-2006 at the Expe- 
rimental Station in Tomaszkowo $\left(53^{\circ} 43^{\prime} \mathrm{N}, 20^{\circ} 25^{\prime} \mathrm{E}\right)$ belonging to the University of Warmia and Mazury in Olsztyn. The experiment was established on brown rusty soil derived from loamy silty sand deposited on slightly loamy sand and loose silty sand. The soil was classified as good rye soil complex and soil class IVb.

The cereal-legume mixture was grown in four crop rotations with a 25 and $50 \%$ proportion of the mixture and its different positions:

- crop rotation A: mixture $\left(\mathrm{A} / 1^{1 *}\right)$ - spring barley - field pea - spring barley;

- crop rotation B: mixture (B/1) - spring barley - spring barley - spring barley;

- crop rotation $\mathrm{C}$ : mixture $(\mathrm{C} / 1)$ - mixture (C/2) - spring barley - spring barley;

- crop rotation D: mixture (D/1) - spring barley - mixture (D/3) - spring barley.

The experiment was set up in a split-plot design, in 4 replications, and it was carried out simultaneously in all the crop rotation fields. The spring barley cultivars 'Rodion' (in the years 1999-2001) and 'Start' (2002-2006) as well as the field pea cultivars 'Albatros' and 'Grapis' were grown as a mixture. Plough tillage was used in the experiment. NPK fertilization varied, depending on the previous crop for the mixture; it was $230 \mathrm{~kg}$ after barley and $250 \mathrm{~kg}$ NPKMg ha- ${ }^{-1}$ after the mixture. The mixture was sown in the 2 nd decade of April at a rate of 175 germinating barley kernels and 41 pea seeds per $1 \mathrm{~m}^{2}$. During the growing season, no chemical control was applied against diseases and weeds, but zoocides were used against the pea moth, Sitona weevils, and bean weevils.

During the study period, agrometeorological conditions varied. On the basis of total rainfall and according to the criteria developed by Kaczorowska and Przedpełska with Szwejkowski's modification (S zwejkowski, 1997), the growing seasons in 2004 and 2006 were classified as wet seasons, those in 2000 and 2001 as average ones, the 2003 growing season was classified as dry, while those in 2002 and 2005 as very dry. On the other hand, in terms of thermal conditions, the growing seasons in 2000, 2001, 2003, and 2006 proved to be warm, whereas those in 2002, 2004, and 2005 were colder.

Weed infestation was assessed each year, twice per growing season: in the spring (during tillering of spring barley) and before the harvest of the mixture. During the first assessment, the weed species composition and density were determined, while during the second assessment air-dry weight of weeds was additionally estimated. The sampling area was delineated

\footnotetext{
* designations of crop rotations and fields with the cereallegume mixture.
}

by a frame with the dimensions of $0.25 \mathrm{~m} \mathrm{x} 1 \mathrm{~m}$, in two replications per plot.

The obtained results were used to determine species constancy, distinguishing classes according to B ra un - B l anquet (1964): V - species occurring constantly or frequently (present in $80.1-100 \%$ of the study years); IV - frequent species (in 60.1-80\%); III - medium frequent (40.1-60\%); II - not very frequent (20.1-40\%); I - sporadic (up to $20 \%$ of the study years). Based on these results, Simpson's dominance index [1949] as well as the Shannon-Wiener diversity and evenness indices ( $\mathrm{S} \mathrm{h}$ a n n o n, 1948; W i e n e r, 1948) were calculated. The indices were calculated using the following formulae:

$$
\begin{aligned}
& \text { Simpson's dominance }():=p \quad{ }_{i}^{2} \\
& \text { Shannon-Wiener diversity }\left(H^{\prime}\right): \\
& H^{\prime}=-\left(p_{i} \times \ln p_{i}\right)
\end{aligned}
$$

Shannon-Wiener evenness $\left(J^{\prime}\right): J^{\prime}=H^{\prime} \times \ln S^{-1}$

where $\mathrm{p}_{\mathrm{i}}-$ the proportion of individuals (biomass) of the $i$ th species to the total numbers (biomass) of the community; $\mathrm{S}$ - the number of species in the community.

The similarity of weed communities was also determined using Sørensen's coefficient (1948) according to the following formula: $\mathrm{P}=2 \mathrm{c} \times 100 \times(\mathrm{a}+\mathrm{b})^{-1}$, where:

$\mathrm{P}-$ the coefficient of similarity expressed in \%;

$\mathrm{c}$ - the total of common species or of their numbers, or their biomass, for a given pair of communities;

a - the total of species or of their numbers, or their biomass, in the first community;

$b$ - the total of species or of their numbers, or their biomass, in the second community.

Weed nomenclature followed $\mathrm{Mirek}$ et al. (2002).

The results were presented as mean values for the 7-year (2000-2006) study period, excluding the first year of the experiment (1999) which was treated as a year used to prepare a proper stand for the cereal-legume mixture. The results relating to total weed numbers and air-dry weight of weeds were subjected to analysis of variance, while the significance of differences was tested by Duncan's test, with a probability of error of 0.05 . The relationships of weed community density and biomass relative to total rainfall and mean temperature during the study period were determined by using coefficients of linear correlation.

\section{RESULTS}

Weed infestation of the mixture of spring barley and field pea grown in crop rotations, differing in the proportion of the mixture (25 and 50\%) and its position in the crop rotation (the mixture grown after itself 
or in the same field with a 1- or 2-year interval in its cultivation), was similar (Tables 1 and 2). At the times of investigation - in the spring and before harvest - a total of 35 taxa were recorded in the floristic lists (in the spring 26-29 were found in the studied plots, including three at the rank of genus, while 26-30 taxa were identified before harvest, including one at the rank of genus). In the spring, Chenopodium album, Echinochloa crus-galli, Fallopia convolvulus, and Sonchus arvensis were constant weeds (constancy class V) in all the treatments, whereas before harvest also Capsella bursa-pastoris and Elymus repens. Among the other taxa, depending on the previous crop, the presence of Viola arvensis, Capsella bursa-pastoris, Thlaspi arvense, and Spergula arvensis was recorded constantly (constancy class V) or frequently (constancy class IV), while at the end of the growing season of the crops Viola arvensis and Avena fatua were noted.

Table 1

Weed species composition, density (plants $\mathrm{m}^{-2}$ ) and constancy in the mixture of spring barley and field pea, the tillering stage of spring barley.

\begin{tabular}{|c|c|c|c|c|c|c|}
\hline \multirow{2}{*}{ Weed species } & \multicolumn{6}{|c|}{ Crop rotations/fields } \\
\hline & $\mathrm{A} / 1$ & $\mathrm{~B} / 1$ & $\mathrm{C} / 1$ & $\mathrm{C} / 2$ & $\mathrm{D} / 1$ & $\mathrm{D} / 3$ \\
\hline Anchusa arvensis & $0.3^{\mathrm{I}}$ & $1.4^{\mathrm{III}}$ & $0.4^{\mathrm{II}}$ & $0.4^{\mathrm{III}}$ & $0.7^{\mathrm{II}}$ & $0.4^{\mathrm{II}}$ \\
\hline Apera spica-venti & & & & & $0.1^{\mathrm{I}}$ & \\
\hline Artemisia vulgaris & & $0.1^{\mathrm{I}}$ & & & & \\
\hline Avena fatua & $3.6^{\mathrm{II}}$ & $2.6^{\mathrm{III}}$ & $1.3^{\mathrm{III}}$ & $4.4^{\mathrm{III}}$ & 6.2 II & $1.6^{\mathrm{II}}$ \\
\hline Capsella bursa-pastoris & $15.7^{\mathrm{v}}$ & $15.7^{\mathrm{IV}}$ & $27.2 \mathrm{v}$ & $26.3 \mathrm{v}$ & $22.9^{\mathrm{v}}$ & $24.2 \mathrm{v}$ \\
\hline Centaurea cyanus & $5.3^{\mathrm{III}}$ & $5.7 \mathrm{III}$ & $2.0^{\mathrm{IV}}$ & $3.3^{\mathrm{III}}$ & $4.4^{\mathrm{III}}$ & $2.7^{\mathrm{IV}}$ \\
\hline Chenopodium album & $121.2^{\mathrm{v}}$ & $85.2^{\mathrm{v}}$ & $40.6^{\mathrm{v}}$ & $42.5^{\mathrm{v}}$ & $98.0^{\mathrm{v}}$ & $97.2^{\mathrm{v}}$ \\
\hline Cirsium arvense & $0.1^{\mathrm{I}}$ & $0.7^{\mathrm{III}}$ & $0.3^{\mathrm{I}}$ & $0.1^{\mathrm{I}}$ & $0.1^{\mathrm{I}}$ & $0.1^{\mathrm{I}}$ \\
\hline Echinochloa crus-galli & $79.0^{\mathrm{v}}$ & $44.0^{\mathrm{v}}$ & $30.9^{\mathrm{v}}$ & $34.0^{\mathrm{v}}$ & $55.3^{\mathrm{v}}$ & $38.9^{\mathrm{v}}$ \\
\hline Elymus repens & $2.7^{\mathrm{IV}}$ & $2.4^{\mathrm{III}}$ & $3.6^{\mathrm{v}}$ & $3.3^{\mathrm{IV}}$ & $2.3^{\mathrm{III}}$ & $1.6^{\mathrm{III}}$ \\
\hline Equisetum arvense & $0.9^{\text {II }}$ & $0.1^{\mathrm{I}}$ & $0.1^{\mathrm{IV}}$ & $0.3^{\text {II }}$ & $0.3^{\mathrm{II}}$ & $0.3^{\mathrm{I}}$ \\
\hline Erodium cicutarium & $0.1^{\mathrm{I}}$ & & $0.3^{\mathrm{II}}$ & $0.3^{\text {II }}$ & $0.3^{\text {II }}$ & \\
\hline Fallopia convolvulus & $13.6^{\mathrm{v}}$ & $8.9^{\mathrm{V}}$ & $8.9^{\mathrm{v}}$ & $11.0^{\mathrm{v}}$ & $16.2^{\mathrm{v}}$ & $15.6^{\mathrm{v}}$ \\
\hline Galeopsis tetrahit & $1.7^{\mathrm{IV}}$ & $1.3^{\mathrm{III}}$ & $2.9^{\mathrm{v}}$ & $2.0^{\mathrm{v}}$ & $2.4^{\mathrm{v}}$ & $2.4^{\mathrm{v}}$ \\
\hline Galinsoga parviflora & $1.4^{\mathrm{IV}}$ & $8.6^{\mathrm{IV}}$ & $0.4^{\mathrm{II}}$ & $1.4^{\mathrm{IV}}$ & $2.7^{\text {III }}$ & $2.7^{\text {III }}$ \\
\hline Galium aparine & $0.6^{\mathrm{III}}$ & $6.1^{\mathrm{v}}$ & $3.1^{\mathrm{v}}$ & $3.4^{\mathrm{v}}$ & $2.9^{\mathrm{v}}$ & $1.7^{\mathrm{v}}$ \\
\hline Geranium pusillum & & $0.1^{\mathrm{I}}$ & & & & \\
\hline Lamium sp. & & $0.1^{\mathrm{I}}$ & $0.1^{\mathrm{I}}$ & $0.1^{\mathrm{I}}$ & & \\
\hline Matricaria maritima subsp. inodora & $1.6^{\mathrm{II}}$ & $6.6^{\mathrm{III}}$ & $11.0^{\mathrm{III}}$ & $10.0^{\mathrm{IV}}$ & $1.4^{\mathrm{II}}$ & $2.0^{\mathrm{III}}$ \\
\hline Mentha arvensis & & & & & $0.1^{\mathrm{I}}$ & \\
\hline Myosotis arvensis & $1.7^{\mathrm{III}}$ & $2.4^{\mathrm{IV}}$ & $2.6^{\mathrm{III}}$ & $3.6^{\mathrm{IV}}$ & $4.7^{\mathrm{v}}$ & $3.0^{\mathrm{IV}}$ \\
\hline Papaver rhoeas & & & & & $0.1^{\mathrm{I}}$ & \\
\hline Pоа аппиа & $0.1^{\mathrm{I}}$ & & & $0.1^{\mathrm{I}}$ & & $0.1^{\mathrm{I}}$ \\
\hline Polygonum aviculare & $0.6^{\mathrm{II}}$ & $2.3^{\mathrm{III}}$ & 0.7 III & $1.0^{\mathrm{III}}$ & $0.3^{\mathrm{I}}$ & $0.4^{\text {II }}$ \\
\hline Polygonum lapathifolium subsp. lapathifolium & $0.3^{\mathrm{I}}$ & $0.3^{\mathrm{II}}$ & $0.3^{\mathrm{II}}$ & $0.6^{\mathrm{III}}$ & $0.7^{\mathrm{II}}$ & $0.1^{\mathrm{I}}$ \\
\hline Raphanus raphanistrum & $0.6^{\mathrm{I}}$ & $0.1^{\mathrm{I}}$ & & $0.3^{\text {II }}$ & $0.3^{\mathrm{II}}$ & $0.4^{\mathrm{III}}$ \\
\hline Sonchus arvensis & $22.1^{\mathrm{v}}$ & $24.3^{\mathrm{v}}$ & $23.7 \mathrm{v}$ & $30.0^{\mathrm{v}}$ & $26.3^{\mathrm{v}}$ & $22.6^{\mathrm{v}}$ \\
\hline Spergula arvensis & $8.1^{\mathrm{v}}$ & $4.1^{\mathrm{IV}}$ & $4.6^{\mathrm{IV}}$ & $4.9^{\mathrm{v}}$ & $4.9^{\mathrm{v}}$ & $5.9^{\mathrm{v}}$ \\
\hline Stellaria media & $0.1^{\mathrm{I}}$ & $3.6^{\mathrm{v}}$ & $1.1^{\mathrm{III}}$ & $4.7^{\mathrm{III}}$ & $1.1^{\mathrm{III}}$ & $0.6^{\mathrm{III}}$ \\
\hline Thlaspi arvense & $2.3^{\mathrm{IV}}$ & $12.6^{\mathrm{v}}$ & $7.0^{\mathrm{v}}$ & $7.4^{\mathrm{IV}}$ & $2.7^{\mathrm{IV}}$ & $2.9^{\mathrm{v}}$ \\
\hline Veronica sp. & $0.6^{\mathrm{III}}$ & $9.2^{\mathrm{IV}}$ & $3.1 \mathrm{IV}$ & $2.4^{\mathrm{IV}}$ & $3.6^{\mathrm{IV}}$ & $2.4^{\mathrm{IV}}$ \\
\hline Vicia sp. & $2.0^{\mathrm{IV}}$ & $7.7^{\mathrm{v}}$ & $3.1^{\mathrm{IV}}$ & $3.3^{\mathrm{III}}$ & $7.1^{\mathrm{IV}}$ & $6.1^{\mathrm{v}}$ \\
\hline Viola arvensis & $10.7^{\mathrm{v}}$ & $19.2^{\mathrm{IV}}$ & $18.0^{\mathrm{v}}$ & $18.0^{\mathrm{v}}$ & $19.2^{\mathrm{v}}$ & $19.7^{\mathrm{v}}$ \\
\hline Total & $297.0 \mathrm{a}$ & $275.4 \mathrm{ab}$ & $197.3 b$ & $219.1 \mathrm{ab}$ & $287.3 \mathrm{ab}$ & $255.6 \mathrm{ab}$ \\
\hline Number of species & 27 & 28 & 26 & 28 & 29 & 26 \\
\hline
\end{tabular}

Explanations:

$\mathrm{I}-\mathrm{V}$ - species constancy

$\mathrm{a}, \mathrm{b}-$ numbers followed by the same letter are not significantly different at $\mathrm{p}=0.05$ 
Table 2

Weed species composition, density (plants $\times \mathrm{m}^{-2}$ ) and constancy in the mixture of spring barley and field pea, before harvest.

\begin{tabular}{|c|c|c|c|c|c|c|}
\hline \multirow{2}{*}{ Weed species } & \multicolumn{6}{|c|}{ Crop rotations/fields } \\
\hline & $\mathrm{A} / 1$ & $\mathrm{~B} / 1$ & $\mathrm{C} / 1$ & $\mathrm{C} / 2$ & $\mathrm{D} / 1$ & $\mathrm{D} / 3$ \\
\hline Anagallis arvensis & & & & & & $0.1^{\mathrm{I}}$ \\
\hline Anchusa arvensis & $1.1^{\mathrm{III}}$ & $0.1^{\mathrm{I}}$ & $0.3^{\text {II }}$ & $0.4^{\mathrm{II}}$ & $1.3^{\mathrm{III}}$ & $0.6^{\mathrm{III}}$ \\
\hline Apera spica-venti & & $10.3^{\mathrm{III}}$ & & & & \\
\hline Avena fatua & $11.7^{\mathrm{IV}}$ & $14.7^{\mathrm{IV}}$ & $21.2^{\mathrm{IV}}$ & $23.6^{\mathrm{IV}}$ & $24.1^{\mathrm{v}}$ & $10.6^{\mathrm{v}}$ \\
\hline Capsella bursa-pastoris & $15.0^{\mathrm{V}}$ & $11.9^{\mathrm{v}}$ & $19.7^{\mathrm{v}}$ & $12.3^{\mathrm{v}}$ & $12.0^{\mathrm{v}}$ & $15.9^{\mathrm{V}}$ \\
\hline Centaurea cyanus & $5.4^{\mathrm{IV}}$ & $4.1^{\mathrm{V}}$ & $3.4^{\mathrm{IV}}$ & $4.4^{\mathrm{IV}}$ & $4.0^{\mathrm{IV}}$ & $3.0^{\mathrm{IV}}$ \\
\hline Chamomilla suaveolens & $0.6^{\mathrm{I}}$ & $0.4^{\mathrm{II}}$ & $0.4^{\mathrm{II}}$ & $0.1^{\mathrm{I}}$ & $0.3^{\mathrm{I}}$ & $0.3^{\mathrm{I}}$ \\
\hline Chenopodium album & $102.9^{\mathrm{V}}$ & $63.9^{\mathrm{v}}$ & $40.3^{\mathrm{v}}$ & $43.2^{\mathrm{V}}$ & $79.9^{v}$ & $87.1^{\mathrm{V}}$ \\
\hline Cirsium arvense & & $0.7^{\mathrm{I}}$ & & & & \\
\hline Crepis tectorum & & & $0.1^{\mathrm{I}}$ & & & $0.3^{\mathrm{I}}$ \\
\hline Echinochloa crus-galli & $102.1^{\mathrm{V}}$ & $36.0^{\mathrm{V}}$ & $35.9^{\mathrm{v}}$ & $40.3^{\mathrm{v}}$ & $45.4^{\mathrm{V}}$ & $56.1^{\mathrm{V}}$ \\
\hline Elymus repens & $25.6^{\mathrm{V}}$ & $24.4^{\mathrm{V}}$ & $26.9^{\mathrm{v}}$ & $29.4^{\mathrm{V}}$ & $19.3^{\mathrm{v}}$ & $24.3^{\mathrm{v}}$ \\
\hline Equisetum arvense & $0.1^{\mathrm{I}}$ & $0.3^{\mathrm{I}}$ & $0.4^{\mathrm{II}}$ & $0.3^{\mathrm{I}}$ & & $0.7^{\mathrm{I}}$ \\
\hline Erodium cicutarium & & $0.1^{\mathrm{I}}$ & & $0.3^{\mathrm{I}}$ & & \\
\hline Euphorbia helioscopia & & & $0.1^{\mathrm{I}}$ & & & \\
\hline Fallopia convolvulus & $27.7^{\mathrm{v}}$ & $12.2^{\mathrm{v}}$ & $15.0^{\mathrm{v}}$ & $14.3^{\mathrm{v}}$ & $14.6^{\mathrm{V}}$ & $17.0^{\mathrm{v}}$ \\
\hline Galeopsis tetrahit & $1.4^{\mathrm{IV}}$ & $0.6^{\mathrm{III}}$ & $1.7^{\mathrm{IV}}$ & $1.7^{\mathrm{IV}}$ & $1.7^{\mathrm{IV}}$ & $0.1^{\mathrm{I}}$ \\
\hline Galinsoga parviflora & $4.6^{\mathrm{IV}}$ & $11.0^{\mathrm{IV}}$ & $4.6^{\mathrm{V}}$ & $3.4^{\mathrm{IV}}$ & $4.3^{\mathrm{IV}}$ & $8.1^{\mathrm{IV}}$ \\
\hline Galium aparine & $0.3^{\mathrm{II}}$ & $4.9^{\mathrm{V}}$ & $4.1^{\mathrm{v}}$ & $3.1^{\mathrm{V}}$ & $1.0^{\mathrm{IV}}$ & $0.9^{\mathrm{IV}}$ \\
\hline Matricaria maritima subsp. inodora & $1.2^{\mathrm{IV}}$ & $1.9^{\mathrm{IV}}$ & $7.0^{\mathrm{IV}}$ & $0.7^{\mathrm{II}}$ & $0.3^{\mathrm{I}}$ & $0.7^{\mathrm{III}}$ \\
\hline Myosotis arvensis & $3.0^{\mathrm{III}}$ & $2.0^{\mathrm{IV}}$ & $3.0^{\mathrm{v}}$ & $3.3^{\mathrm{v}}$ & $1.7^{\mathrm{IV}}$ & $1.3^{\mathrm{III}}$ \\
\hline Plantago major & $0.4^{\mathrm{II}}$ & $0.4^{\mathrm{III}}$ & $0.3^{\mathrm{I}}$ & & $0.1^{\mathrm{I}}$ & $0.3^{\mathrm{II}}$ \\
\hline Polygonum aviculare & $0.6^{\mathrm{II}}$ & $0.1^{\mathrm{I}}$ & $1.0^{\mathrm{III}}$ & $0.3^{\mathrm{II}}$ & $1.7^{\mathrm{III}}$ & \\
\hline Polygonum lapathifolium subsp. lapathifolium & $1.0^{\mathrm{I}}$ & $0.3^{\mathrm{II}}$ & $0.7^{\mathrm{III}}$ & $0.3^{\mathrm{I}}$ & $1.1^{\mathrm{II}}$ & $2.9^{\mathrm{II}}$ \\
\hline Raphanus raphanistrum & $0.1^{\mathrm{I}}$ & & & $0.1^{\mathrm{I}}$ & $0.1^{\mathrm{I}}$ & \\
\hline Setaria viridis & $4.9^{\mathrm{IV}}$ & $1.3^{\mathrm{III}}$ & $0.3^{\mathrm{I}}$ & $0.4^{\mathrm{II}}$ & & $0.1^{\mathrm{I}}$ \\
\hline Sonchus arvensis & $22.0^{\mathrm{v}}$ & $18.0^{\mathrm{V}}$ & $28.6^{\mathrm{v}}$ & $32.6^{\mathrm{v}}$ & $24.9^{\mathrm{v}}$ & $17.6^{\mathrm{v}}$ \\
\hline Spergula arvensis & $4.3^{\mathrm{v}}$ & $1.1^{\mathrm{III}}$ & $2.1^{\mathrm{v}}$ & $0.7^{\mathrm{III}}$ & $2.9^{\mathrm{IV}}$ & $2.0^{\mathrm{IV}}$ \\
\hline Stellaria media & $\mathrm{x}^{\mathrm{II}}$ & $x^{\text {IV }}$ & $x^{\text {IV }}$ & $x^{\text {IV }}$ & $\mathrm{X}^{\mathrm{II}}$ & $x^{I I}$ \\
\hline Thlaspi arvense & $0.9^{\mathrm{IV}}$ & $3.3^{\mathrm{III}}$ & $2.0^{\mathrm{IV}}$ & $3.1^{\mathrm{IV}}$ & $1.7^{\mathrm{II}}$ & $2.6^{\mathrm{II}}$ \\
\hline Veronica arvensis & $1.4^{\mathrm{III}}$ & $0.4^{\mathrm{II}}$ & $1.4^{\mathrm{III}}$ & $0.6^{\mathrm{II}}$ & $0.4^{\mathrm{III}}$ & $0.6^{\mathrm{II}}$ \\
\hline Veronica persica & $0.4^{\mathrm{III}}$ & $3.0^{\mathrm{III}}$ & $1.1^{\mathrm{I}}$ & $0.9^{\mathrm{II}}$ & $0.9^{\mathrm{II}}$ & $2.1^{\mathrm{III}}$ \\
\hline Vicia sp. & $2.4^{\mathrm{IV}}$ & $3.1^{\mathrm{IV}}$ & $2.9^{\mathrm{IV}}$ & $2.6^{\mathrm{IV}}$ & $3.9^{\mathrm{IV}}$ & $4.0^{\mathrm{v}}$ \\
\hline Viola arvensis & $8.6^{\mathrm{IV}}$ & $5.9^{\mathrm{IV}}$ & $14.3^{\mathrm{v}}$ & $7.6^{\mathrm{v}}$ & $7.7^{\text {IV }}$ & $9.6^{\mathrm{v}}$ \\
\hline Total & $349.7 \mathrm{a}$ & $236.4 \mathrm{ab}$ & $238.8 \mathrm{ab}$ & $230.0 \mathrm{~b}$ & $255.3 \mathrm{ab}$ & $269.9 \mathrm{ab}$ \\
\hline Number of species & 28 & 30 & 29 & 28 & 26 & 28 \\
\hline
\end{tabular}

Explanations:

$\mathrm{I}-\mathrm{V}$ - species constancy

$\mathrm{x}$ - density was not calculated

$\mathrm{a}, \mathrm{b}$ - numbers followed by the same letter are not significantly different at $\mathrm{p}=0.05$

The position of the mixture in the crop rotation affected its weed infestation (Tables 1 and 2). In the spring, the lowest weed infestation of the segetal flora was observed in crop rotation $\mathrm{C}$ - fields 1 and 2 , when spring barley was grown twice and then the mixture of barley and pea was sown for the next 2 years -197.3 and 219.1 plants $\times \mathrm{m}^{-2}$ (Table 1$)$. When there was an interval in growing the mixture after itself (crop rotations A, B and D), this promoted weed emergence, in particular in the four crop rotation with field pea (crop rotation A). The adverse effect of the leguminous plant used as the previous crop deepened during the growing period, and the numbers of weeds increased from 297 plants in the spring (Table 1) to nearly 350 plants $\times \mathrm{m}^{-2}$ before harvest (Table 2 ). In this treatment (A/1), weed infestation of the mixture was even significantly higher than in the treatment when it was sown after itself $(\mathrm{C} / 2)$. On the other hand, the proportion and position of the mixture in the crop rotations were not found to have a significant effect on total weed biomass, which ranged 138.7-161.2 $\mathrm{g} \times$ $\mathrm{m}^{-2}$ (Table 3). 
Table 3

Air-dry weight of weeds in the mixture of spring barley and field pea, before harvest, $\mathrm{g} \times \mathrm{m}^{-2}$.

\begin{tabular}{|c|c|c|c|c|c|c|}
\hline \multirow{2}{*}{ Weed species } & \multicolumn{6}{|c|}{ Crop rotations/fields } \\
\hline & $\mathrm{A} / 1$ & $\mathrm{~B} / 1$ & $\mathrm{C} / 1$ & $\mathrm{C} / 2$ & $\mathrm{D} / 1$ & $\mathrm{D} / 3$ \\
\hline Anagallis arvensis & & & & & & $<0.1$ \\
\hline Anchusa arvensis & 1.6 & 0.1 & 0.1 & 0.3 & 0.6 & 0.4 \\
\hline Apera spica-venti & & 10.3 & & & & \\
\hline Avena fatua & 14.1 & 17.0 & 26.5 & 35.2 & 26.6 & 16.0 \\
\hline Capsella bursa-pastoris & 1.7 & 2.3 & 4 & 2.3 & 2.1 & 2.3 \\
\hline Centaurea cyanus & 7.8 & 6.0 & 4.5 & 7.4 & 4.9 & 7.4 \\
\hline Chamomilla suaveolens & $<0.1$ & $<0.1$ & $<0.1$ & $<0.1$ & 0.1 & $<0.1$ \\
\hline Chenopodium album & 50.0 & 37.4 & 18.4 & 21.6 & 47.5 & 51.8 \\
\hline Cirsium arvense & & 4.1 & & & & \\
\hline Crepis tectorum & & & 0.1 & & & 0.1 \\
\hline Echinochloa crus-galli & 13.4 & 13.8 & 12.7 & 18.1 & 13.6 & 13.5 \\
\hline Equisetum arvense & 0.2 & 0.2 & 0.5 & 0.3 & & 0.6 \\
\hline Elymus repens & 9.4 & 13.8 & 14.0 & 19.6 & 10.3 & 9.2 \\
\hline Erodium cicutarium & & $<0.1$ & & 0.1 & & \\
\hline Euphorbia helioscopia & & & $<0.1$ & & & \\
\hline Fallopia convolvulus & 10.0 & 6.3 & 8.9 & 7.5 & 7.9 & 9.3 \\
\hline Galeopsis tetrahit & 0.5 & 0.4 & 2.1 & 1.7 & 1.0 & $<0.1$ \\
\hline Galinsoga parviflora & 0.8 & 3.1 & 1.9 & 1.5 & 0.7 & 2.0 \\
\hline Galium aparine & $<0.1$ & 2.6 & 1.9 & 1.7 & 1.1 & 0.5 \\
\hline Matricaria maritima subsp. inodora & 0.7 & 3.9 & 1.7 & 0.4 & $<0.1$ & 0.4 \\
\hline Myosotis arvensis & 0.5 & 0.5 & 0.5 & 0.4 & 0.4 & 0.1 \\
\hline Plantago major & $<0.1$ & 0.1 & $<0.1$ & & $<0.1$ & $<0.1$ \\
\hline Polygonum aviculare & $<0.1$ & $<0.1$ & 0.4 & 0.1 & 0.4 & \\
\hline Polygonum lapathifolium subsp. lapathifolium & 0.7 & 0.3 & 0.3 & 0.1 & 0.7 & 0.3 \\
\hline Raphanus raphanistrum & 0.1 & & & 0.1 & 0.9 & \\
\hline Setaria viridis & 0.4 & $<0.1$ & $<0.1$ & $<0.1$ & & $<0.1$ \\
\hline Sonchus arvensis & 22.2 & 27.6 & 47.7 & 38.9 & 34.6 & 19.1 \\
\hline Spergula arvensis & 1.5 & 0.3 & 0.6 & 0.1 & 0.4 & 0.4 \\
\hline Stellaria media & 0.3 & 1.0 & 0.9 & 0.3 & 0.4 & $<0.1$ \\
\hline Thlaspi arvense & 0.2 & 0.3 & 0.4 & 0.6 & 0.3 & 0.3 \\
\hline Veronica arvensis & 0.1 & $<0.1$ & 0.1 & $<0.1$ & $<0.1$ & $<0.1$ \\
\hline Veronica persica & $<0.1$ & 0.4 & 0.2 & $<0.1$ & $<0.1$ & 0.3 \\
\hline Vicia sp. & 1.8 & 2.4 & 2.7 & 1.9 & 3.8 & 6.1 \\
\hline Viola arvensis & 0.7 & 0.8 & 1.5 & 1.0 & 1.1 & 1.3 \\
\hline Total & $138.7 \mathrm{a}$ & $155.0 \mathrm{a}$ & $152.6 \mathrm{a}$ & $161.2 \mathrm{a}$ & $159.4 \mathrm{a}$ & $141.7 \mathrm{a}$ \\
\hline
\end{tabular}

Explanations:

$\mathrm{a}$ - numbers followed by the same letter are not significantly different at $\mathrm{p}=0.05$

The analysis of the quantitative structure of the weed communities showed that the numbers of taxa and the relationships between them varied in the spring barley and field pea mixture crops in the plots compared. At the tillering stage of spring barley, the population of Chenopodium album, followed by Echinochloa crus-galli, was characterized by the highest density and, at the same time, the highest proportion in the total numbers of the community, irrespective of the concentration of the mixture in the crop rotation and its position. Crop selection and sequence promoted the emergence of these species, in particular in crop rotation A - respectively, on average 121.2 plants $\mathrm{m}^{-2}$ (accounting for $40.8 \%$ ) and 79.0 plants $\mathrm{m}^{-2}(26.6 \%$ of the total number of weeds). Chenopodium album and Echinochloa crus-galli also emerged in great numbers in crop rotations $\mathrm{B}$ (treatment $\mathrm{B} / 1)$ and $\mathrm{D}(\mathrm{D} / 1$ and $D / 3$ ). The density of the other more abundant taxa in the fields of the crop rotations compared was similar. Before harvest, Chenopodium album and Echinochloa 
crus-galli still maintained their quantitative advantage over the other weed species. This situation was best seen in the four crop rotation with field pea and with the 50\% proportion of spring barley (crop rotation A, field 1), where the density of the populations of these species exceeded 100 plants $\mathrm{m}^{-2}$ (altogether, more than $58 \%$ of the total number of weeds). In terms of the numbers, the following species also distinguished themselves: Sonchus arvensis (accounting for $6.3-14.2 \%$ of the total number of weeds), Avena $\mathrm{fa}$ tua (3.3-10.3\%), Elymus repens (7.3-12.8\%), Fallopia convolvulus (5.2-7.9\%), and Capsella bursa-pastoris (4.3-8.2\%). The above-mentioned taxa also determined the total biomass of unwanted vegetation and the biomass relationships between them were differentiated by the proportion and position of the mixture in the crop rotation. In the 4-year crop rotations $\mathrm{A}, \mathrm{B}$, and $\mathrm{D}$, the highest air-dry weight was recorded for Chenopodium album, followed by Sonchus arvensis and Avena fatua, while in crop rotation $\mathrm{C}$ (fields $\mathrm{C} / 1$ and $\mathrm{C} / 2$ ) the positions of these species were as follows in the decreasing order: Sonchus arvensis, Avena fatua, and Chenopodium album. Irrespective of the position of the cereal-legume mixture in the crop rotation, the total biomass of the three above-mentioned species ac- counted for more than $50 \%$ of total air-dry weight of weeds.

The relationships of population numbers between particular species, expressed by means of the dominance, diversity and evenness indices, show crop rotation A to have greater dominance in the weed communities, but at the same time lower species diversity was found in the spring (Table 4). The presence of field pea in the crop rotation probably promoted the accumulation of weed diaspores in the soil and subsequently weed infestation of the crop by the emergence of Chenopodium album and Echinochloa crus-galli in great numbers. Growing the mixture of spring barley and field pea had a beneficial effect on the differentiation of the segetal phytocenoses in the fields of the other crop rotations (B, C, D), which manifested itself in an increase in the values of the calculated Shannon-Wiener indices (species diversity above 2 and weed species evenness above 0.6 ). This trend continued until the harvest of the cereal-legume mixture. The presented dominance, diversity and evenness indices calculated based on weed biomass were similar, which is evidence that the proportion of the cereal-legume mixture in the crop rotation and the selection of its position only slightly differentiate the biomass of segetal plants.

Table 4

The dominance, diversity and evenness indices for weed communities in the mixture of spring barley and field pea.

\begin{tabular}{|c|c|c|c|c|c|c|}
\hline \multirow{2}{*}{ Indices } & \multicolumn{6}{|c|}{ Crop rotations/fields } \\
\hline & $\mathrm{A} / 1$ & $\mathrm{~B} / 1$ & $\mathrm{C} / 1$ & $\mathrm{C} / 2$ & $\mathrm{D} / 1$ & $\mathrm{D} / 3$ \\
\hline \multicolumn{7}{|c|}{ tillering of spring barley - based on weed density } \\
\hline & 0.251 & 0.145 & 0.117 & 0.110 & 0.178 & 0.196 \\
\hline $\mathrm{H}^{\prime}$ & 1.870 & 2.422 & 2.448 & 2.527 & 2.206 & 2.119 \\
\hline $\mathrm{J}$ & 0.567 & 0.727 & 0.751 & 0.758 & 0.655 & 0.650 \\
\hline \multicolumn{7}{|c|}{ before harvest of the mixture - based on weed density } \\
\hline & 0.192 & 0.128 & 0.103 & 0.122 & 0.161 & 0.172 \\
\hline $\mathrm{H}^{\prime}$ & 2.089 & 2.465 & 2.532 & 2.373 & 2.235 & 2.206 \\
\hline J' & 0.630 & 0.725 & 0.752 & 0.712 & 0.686 & 0.622 \\
\hline \multicolumn{7}{|c|}{ before harvest of the mixture - based on air-dry weight of weeds } \\
\hline & 0.189 & 0.128 & 0.164 & 0.156 & 0.180 & 0.187 \\
\hline $\mathrm{H}^{\prime}$ & 2.074 & 2.386 & 2.205 & 2.123 & 2.055 & 2.076 \\
\hline $\mathrm{J}^{\prime}$ & 0.622 & 0.701 & 0.655 & 0.637 & 0.631 & 0.623 \\
\hline
\end{tabular}

-Simpson's dominance index

H' -Shannon-Wiener diversity index

J' - Shannon-Wiener evenness index

The weed communities developed in the cereal-legume mixture crops in the crop rotations under assessment showed a high analogy in floristic richness as well as in the numbers and biomass of particular segetal species (Table 5). They were more similar in terms of their species composition than in terms of the density of particular species and biomass produced by them. The high floristic similarity was maintained until the end of the growing season of the cereal-legume mixture. Among the pairs of the communities analysed, the lowest similarity was between the phytocenoses of the cereal-legume mixture crop from field 1 of crop rotation A in relation to fields 1 and 2 of crop rotation $\mathrm{C}$ (the weed similarity index below $70 \%$ based on weed numbers and biomass) as well as between the phytocenoses of fields 1 and 2 of crop rotation $\mathrm{C}$ in relation to 
field 3 of crop rotation $\mathrm{D}$ (the calculated index below $70 \%$ for weed biomass).

Weed infestation of the cereal-legume mixture in the spring was significantly correlated with rainfall and mean temperature in April (Table 6). Weed emer- gence was promoted by higher rainfall and lower air temperature. During the summer growing season, a significant positive correlation was shown between July temperature as well as the numbers and air-dry weight of the segetal phytocenoses.

Table 5

Similarity indices for weed communities, in \%.

\begin{tabular}{|c|c|c|c|c|c|}
\hline \multirow{3}{*}{$\begin{array}{l}\text { Crop rotation } \\
\text { fields compared }\end{array}$} & \multicolumn{2}{|c|}{ Tillering stage of barley } & \multicolumn{3}{|c|}{ Before harvest of the mixture } \\
\hline & \multicolumn{5}{|c|}{ based on } \\
\hline & species composition & density & species composition & density & air-dry weight \\
\hline $\mathrm{A} / 1-\mathrm{B} / 1$ & 87.3 & 74.8 & 96.6 & 69.9 & 79.5 \\
\hline $\mathrm{A} / 1-\mathrm{C} / 1$ & 88.9 & 61.5 & 94.7 & 63.3 & 67.8 \\
\hline $\mathrm{A} / 1-\mathrm{C} / 2$ & 92.9 & 63.8 & 96.4 & 67.9 & 68.8 \\
\hline $\mathrm{A} / 1-\mathrm{D} / 1$ & 89.3 & 83.6 & 96.3 & 77.6 & 85.5 \\
\hline $\mathrm{A} / 1-\mathrm{D} / 3$ & 92.6 & 81.0 & 89.3 & 82.6 & 93.0 \\
\hline $\mathrm{B} / 1-\mathrm{C} / 1$ & 87.3 & 75.1 & 91.5 & 79.6 & 74.4 \\
\hline $\mathrm{B} / 1-\mathrm{C} / 2$ & 87.7 & 76.7 & 93.1 & 81.2 & 73.8 \\
\hline $\mathrm{B} / 1-\mathrm{D} / 1$ & 84.2 & 84.4 & 92.9 & 82.1 & 80.4 \\
\hline $\mathrm{B} / 1-\mathrm{D} / 3$ & 87.3 & 84.3 & 89.7 & 81.4 & 79.2 \\
\hline $\mathrm{C} / 1-\mathrm{C} / 2$ & 89.3 & 92.8 & 91.2 & 91.1 & 85.9 \\
\hline $\mathrm{C} / 1-\mathrm{D} / 1$ & 85.7 & 72.8 & 90.9 & 80.4 & 80.7 \\
\hline $\mathrm{C} / 1-\mathrm{D} / 3$ & 85.2 & 76.8 & 94.7 & 75.0 & 68.0 \\
\hline $\mathrm{C} / 2-\mathrm{D} / 1$ & 86.2 & 76.1 & 92.6 & 84.3 & 80.2 \\
\hline $\mathrm{C} / 2-\mathrm{D} / 3$ & 89.3 & 77.6 & 89.3 & 75.3 & 68.1 \\
\hline $\mathrm{D} / 1-\mathrm{D} / 3$ & 85.7 & 92.7 & 88.9 & 89.9 & 85.3 \\
\hline
\end{tabular}

Table 6

Correlation of the numbers and air-dry weight of weeds in relation to rainfall and temperature during the study period.

\begin{tabular}{|c|c|c|}
\hline Specification & Density & Air-dry weight \\
\hline \multicolumn{3}{|c|}{ tillering stage of barley } \\
\hline \multicolumn{3}{|l|}{ April } \\
\hline - rainfall & $0.45^{*}$ & \\
\hline - temperature & $-0.40 *$ & \\
\hline \multicolumn{3}{|c|}{ before harvest of the mixture } \\
\hline \multicolumn{3}{|l|}{ May } \\
\hline - rainfall & -0.17 & -0.10 \\
\hline - temperature & 0.00 & 0.13 \\
\hline \multicolumn{3}{|l|}{ June } \\
\hline - rainfall & 0.38 & 0.26 \\
\hline - temperature & 0.05 & -0.15 \\
\hline \multicolumn{3}{|l|}{ July } \\
\hline - rainfall & -0.06 & 0.20 \\
\hline - temperature & $0.32 *$ & $0.37 *$ \\
\hline \multicolumn{3}{|l|}{ August } \\
\hline - rainfall & -0.26 & -0.08 \\
\hline - temperature & 0.13 & 0.10 \\
\hline \multicolumn{3}{|l|}{ April - August } \\
\hline - rainfall & -0.05 & 0.18 \\
\hline - temperature & -0.04 & 0.22 \\
\hline
\end{tabular}




\section{DISCUSSIONS}

The competitive ability of crop plants grown in mixtures in relation to weeds is sometimes insufficient to maintain weed infestation at a safe level ( $\mathrm{R} \mathrm{u} \mathrm{d} \mathrm{n} \mathrm{i} \mathrm{c} \mathrm{-}$ $\mathrm{ki}$ and $\mathrm{Wenda-Piesik,2002).} \mathrm{That} \mathrm{is} \mathrm{why} \mathrm{pro-}$ per crop selection and sequence in a crop rotation is so important, as one of the functions of crop rotation is weed management. This aspect is poorly known with regard to cereal-legume mixtures. The present study showed that sowing the mixture after itself in the plot after 2-year cultivation of spring barley contributes to reduced weed density, while the presence of field pea, as a previous crop for the mixture, in the crop rotation promotes weed emergence. But the study found no significant effect of the position on the biomass of segetal plants.

Weed infestation of cereal-legume mixtures is usually similar to weed infestation of cereal crops in pure stand and by far lower than that of pea in pure stand (Sobkowicz and Podgórska-Lesiak, 2007; B u r a c z y ń s k a , 2009). Weed infestation of a mixture of spring barley and field pea demonstrated in an earlier study of the present authors was comparable to that found in spring barley, which was also the subject of investigation in this field experiment (Ko strzew ska, 2009). The similarity also relates to the species composition of unwanted vegetation. However, characterizing weed infestation by means of Shannon's dominance and evenness indices, $\mathrm{P}$ o g g i o (2005) did not find any significant differences between weed communities in a cereal-legume mixture (barley with pea) and in barley in pure stand.

Weed infestation of cereal-legume mixtures depends on the selection of components as well as on their density and proportion in the mixture. The study of S taniak and K si ężak (2010) showed that a mixture of spring barley and field pea demonstrated higher weed infestation than an oat and vetch mixture, but it was characterized by a greater diversity of the weed species composition. On the other hand, $\mathrm{H} \mathrm{a} \mathrm{u} \mathrm{g}$ $\mathrm{g}$ a a r d- Ni e ls e n et al. (2006) found that, with a lower total plant density of the mixture, an increase in the proportion of barley in the mixture caused a clear decrease in weed biomass.

Variation in weed infestation found in cultivated crops is a result of not only the effects of agrotechnical factors (J e d r u s z c z a k et al. 2006), but also of varying weather patterns $(\mathrm{Sobkowicz}$ and $\mathrm{Pod}$ górska-Lesiak, 2007; Szpunar-Krok et al. 2009). The present research and the study $\mathrm{K} \mathrm{u} \mathrm{r} \mathrm{u} \mathrm{s}$ (2010) have confirmed that increased weed infestation of a cereal-legume mixture is promoted by higher temperature in the summer months and that the effect of air humidity can be significant both in the spring and summer.

\section{CONCLUSIONS}

Weed infestation of the mixture of spring barley and field pea was differentiated by crop selection in the crop rotation. The presence of pea in the crop rotation promoted an increase in the number of weeds in the crop, in particular in the case of the crop rotation with the $50 \%$ proportion of the mixture grown after itself.

Elymus repens, Capsella bursa-pastoris, Chenopodium album, Echinochloa crus-galli, Polygonum convolvulus, and Sonchus arvensis were constant weeds in the mixed spring barley and field pea crops. The populations of Chenopodium album and Echinochloa crus-galli distinguished themselves in terms of their numbers, whereas Avena fatua, Chenopodium album and Sonchus arvensis - in terms of their air-dry weight.

The increased dominance of weeds in the phytocenoses being formed was promoted by the cultivation of the cereal-legume mixture in the 4-year crop rotation with field pea, while an increase of its proportion in the crop rotation promoted greater species diversity.

The weed communities were more similar in terms of their floristic composition than in terms of weed density and air-dry weight of weeds.

\section{Acknowledgements}

Research supported by the Ministry of Science and Higher Education of Poland as the part of statutory activities of Department of Agricultural Systems, University of Warmia and Mazury in Olsztyn.

\section{REFERENCES}

B rau n-B la nquet I., 1964. Pflanzensoziologie. Grundzuge der Vegetationskunde. Springer Verlag, Vienna, New York (in German).

B u ra c z y ń sk a D ., 2009. Zachwaszczenie mieszanek strączkowo-zbożowych przy zróżnicowanym składzie ilościowo-jakościowym. / Weed infestation of legume-cereal mixtures associated with different quantitative and qualitative composition. Progress in Plant Protection / Postępy w Ochronie Roślin 49(2): 779-783 (in Polish).

Haugga ard-Nielsen, H., Andersen, M.K., Jørnsga ard, B., Jensen, E.S., 2006. Density and relative frequency effects on competitive interactions and resource use in pea-barley intercrops. Field Crops Res. 95: 256-267.

Jędruszczak M., Dąbek-Gad M., Owczarczuk A., 2006. Chwasty zbóż w gospodarstwie ekologicznym oraz ich ograniczanie za pomocą wsiewek międzyplonowych i mieszanki zbożowo-strączkowej. / Weed flora at ecological farm and its control by intercrops and cereal-pulse crop mixture. Progress in Plant Protection / Postępy w Ochronie Roślin 46(2): 145-148 (in Polish).

Kostrzewska M.K., 2009. Znaczenie mieszanki zbożowo-strączkowej w płodozmianach z różnym udziałem 
jęczmienia jarego. Wyd. UWM Olsztyn, Rozprawy i monografie 150, 1-115 (in Polish).

Kurus J., 2010. Następczy wpływ ugorowania pola na zachwaszczenie łanu żyta. / Consecutive effect of field fallowing on rye weed infestation. Ann. UMCS, sect. E, 65: 81-89 (in Polish).

Mirek Z., Piękoś-Mirkowa H., Zając A., Zając M., 2002. Flowering plants and pteridophytes of Poland. A checklist. Wyd. Inst. Bot. PAN, Kraków: ss. 442.

Poggio, S.L., 2005. Structure of weed communities occurring in monoculture and intercropping of field pea and barley. Agriculture, Ecosystems and Environment. 109: 48-58.

Rudnicki F., 1999. Środowiskowe uwarunkowania uprawy mieszanek zbożowych i zbożowo-strączkowych. [In:] Przyrodnicze i produkcyjne aspekty uprawy roślin w mieszankach. Ogólnopolska Konferencja Naukowa, Poznań 2-3 grudnia 1999: 28-38.

Rudnicki F., Wenda-Piesik A., 2002. Możliwości zastosowania herbicydów w uprawach mieszanych grochu ze zbożami jarymi. / Possibilities of herbicide treatments in the mixtures of pea with spring cereals. Progress in Plant Protection / Postępy w Ochronie RoŚlin 42(2): 551-553 (in Polish).

Shannon C.E., 1948. A mathematical theory of communication. Bell Syst. Tech. J. 27: 379-423.

Simps on E.H., 1949. Measurement of diversity. Nature, 163: 688.

Sobkowicz P., Podgórska-Lesiak M., 2007. Zmiany w zachwaszczeniu zasiewów czystych i mieszanek dwóch odmian grochu $\mathrm{z}$ jęczmieniem pod wpływem nawożenia azotowego. / Changes in weed infestation in pure stands and mixtures of two pea cultivars with barley affected by nitrogen fertilization. Progress in Plant Protection / Postępy w Ochronie Roślin, 47(3): 271-275 (in Polish).

Sørens en T., 1948. A method of establishing groups of equal amplitude in plant society based on similarity of species content. K. Danske Vidensk. Selesk. 5: 1-34.

St aniak M., K siężak J., 2010. Zachwaszczenie mieszanek strączkowo-zbożowych uprawianych ekologicznie. / Weed infestation of legume-cereal mixtures cultivated in organic farming. J. Res. Applic. Agricult. Eng. 55(4): 121-125 (in Polish).

Szpunar-Krok E., Bobrecka-Jamro D., Buczek J., Tobiasz-Salach R., 2009. Wpływ poziomu intensywności uprawy na bioróżnorodność flory zachwaszczającej mieszankę wyki siewnej z jęczmieniem jarym. / The effects of cultivation intensity on the biodiversity of weeds occurring in common vetch mixture with spring barley. Fragm. Agron. 26(4): 170-180 (in Polish).

Szwejkowski Z ., 1997. Badania ważniejszych elementów agroklimatu i ich wpływ na plonowanie wybranych roślin uprawnych. Zakład Agrometeorologii ART w Olsztynie (maszynopis) (in Polish).

Wiener, N., 1948. Cybernetics, or control and communication in the animal and the machine. Cambridge, MA: The MIT Press: 194.

\section{Zachwaszczenie mieszanki zbożowo-strączkowej w zależności od jej koncentracji i usytuowania w płodozmianie}

\section{Streszczenie}

Badania polowe prowadzono w latach 20002006 w Stacji Dydaktyczno-Doświadczalnej w Tomaszkowie należącej do UWM w Olsztynie. Ich celem było porównanie zachwaszczenia mieszanki jęczmienia jarego $\mathrm{z}$ grochem siewnym uprawianej w 4-polowych płodozmianach o różnym doborze i następstwie roślin. Corocznie, podczas krzewienia jęczmienia jarego i przed zbiorem mieszanki, oceniano skład gatunkowy i zagęszczenie gatunków chwastów, a przed zbiorem dodatkowo także ich biomasę. Wyniki te posłużyły do ustalenia stałości występowania gatunków, wskaźników: dominacji Simpsona oraz różnorodności i równomierności Shannona-Wienera, a także podobieństwa zbiorowisk według bogactwa florystycznego, liczebności i biomasy poszczególnych gatunków chwastów. Częstotliwość uprawy i stanowisko w płodozmianie nie różnicowały składu gatunkowego oraz całkowitej masy zbiorowisk chwastów w łanach mieszanki zbożowo-strączkowej. Ograniczająco na liczebność chwastów wpływał płodozmian, w którym mieszanka stanowiła $50 \%$ i była wysiewana po sobie. Uprawa grochu siewnego w 4-letniej rotacji sprzyjała zachwaszczeniu mieszanki i dominacji w zbiorowiskach chwastów. Stałymi elementami agrofitocenoz były Capsella bursa-pastoris, Chenopodium album, Echinochloa crus-galli, Elymus repens, Polygonum convolvulus i Sonchus arvensis. Zbiorowiska chwastów były bardziej podobne pod względem składu florystycznego niż zagęszczenia i powietrznie suchej masy gatunków. 
